Regular Research Article

\title{
From voluntary private to mandatory state governance in Indonesian forest certification: Reclaiming authority by bureaucracies
}

\author{
Agung Wibowo ${ }^{1}$ and Lukas Giessen ${ }^{2,3, *}$ \\ 1 Department of Forestry, Faculty of Agriculture, University of Palangka Raya, Indonesia \\ 2 Chair of Forest and Nature Conservation Policy, University of Göttingen, Germany \\ 3 European Forest Institute (EFI), Bonn Office \\ * Corresponding author: agungwi@for.upr.ac.id; Lukas.Giessen@efi.int
}

\begin{abstract}
Forest certification has been introduced by non-state actors as a voluntary and market-based instrument addressing forest problems, which state policies failed to resolve. Lately, however, state-driven forest-related certification schemes can be observed, e.g. in Indonesia, through the EU FLEGT-VPA negotiation process. It is argued, specific state agencies in a struggle for power and authority develop mandatory certification schemes which are directly competing with private ones. Before this background, the aims of this study are: (i) describing the current trend from voluntary private to mandatory state certification schemes in Indonesia, (ii) mapping the main actors involved in certification politics, and (iii) explaining this trend with the interests of the main actors. The results confirm a trend from voluntary private to mandatory state-driven certification of forest management. The Ministry of Forestry, the Ministry of Trade, the Ministry of Industry, wood producer and processing associations, European Union, local funding organizations, environmental organizations, certification bodies and international buyers are detected as the main coalitions and actors in the certification politics. The stronger coalition develops a mandatorily-timber legality verification system as strategies to counter their voluntary private competitor schemes.
\end{abstract}

Keywords: competition; forest certification; international governance; private governance; state governance; bureaucratic politics; forest policy

\section{Introduction}

As a response to the failed negotiations among governments on a global forest convention in 1992, forest certification has subsequently been introduced by non-governmental actor coalitions for promoting sustainable forest management (Boström, 2003; McDermott, 2014). There are two ideas underlying the emergence of the non-state-actor driven certification schemes, such as the Forest Steward Council (FSC). First, it was an effort by environmental non-governmental organizations to voluntarily certify responsible-managed forest in Europe and North America (Bartley, 2007). Second, such non-state, market-driven, and voluntary forest certification schemes also aimed to certify tropical and mega-diversity forests including problems such as vast deforestation, degradation and illegal logging (Gulbrandsen, 2004; Blackman et al., 2014).

Shortly after the FSC was launched in 1993, other voluntary, non-state certification schemes that were better known locally and that had more support from industry groups were founded during the 1990s to better accommodate local forestry practices. These included e.g. the Sustainable Forestry Initiative (SFI) and the American Tree Farm System (ATFS) in North America, the Programme for the Endorsement of Forest Certification (PEFC, initially the Pan-European Forest Certification) in Europe, the Sustainable Forest Management System in Canada, and Lembaga Ekolabel Indonesia (LEI) in Indonesia (Tosun, 2012; Maryudi 2006, 2009). All these forest certification initiatives have been largely driven by non-state, private actors and voluntary subscription and are consequently regarded as private institutions (Pattberg, 2007). They, yet, 
mirror an underlying competition between public and private actors over the authority to regulate forest management practices (Sikor, 2013).

However, the success of private certification schemes in tackling specific forestry problems like illegal logging, forest encroachment and deforestation, and in improving forest governance in developing countries thus far has been limited (Durst et al., 2006; Tacconi, 2007; Espach, 2006). As a consequence, a state-driven, inter-governmental cooperation between timber producer and consumer countries was initiated by the European Union (EU) in 2003, known as Forest Law Enforcement, Governance and Trade (FLEGT), aiming to certify the legality of harvested timber (Wiersum and Elands, 2013). Such state-based forest certification initiatives now counter-compete with private ones and are assumed having the potential to dominate and even replace private certification schemes (Nurrochmat et al., 2014; Malets, 2015).

Recent empirical findings support this latter perspective and suggest even a crucial role for state agencies in forest certification and related politics (Gale and Haward, 2011; Gulbrandsen, 2014; Sahide et al., 2015). According to these literatures state agencies can obstruct (Gale and Haward, 2011) or support certification initiatives (Hysing, 2009; Bell and Hindmoor, 2012). More importantly, however, specific state bureaucracies, due to their formal mandate and ability to develop binding regulatory policy instruments, may even develop own certification schemes, as currently observed under the FLEGT process and regarding timber legality verification in Indonesia (Nurrochmat et al., 2014). In so doing, it is argued, state agencies develop mandatory certification schemes which are directly competing with private ones, mainly with foreign initiatives, and by this reclaim authority over forest certification through legitimized public actors (Giessen et al., 2016). Before this background, the aims of this study are (i) describing the current trend from voluntary private to mandatory state certification schemes in Indonesia, (ii) mapping the main actors involved in certification politics, and (iii) explaining this trend with the interests of the main actors.

\section{Conceptual framework}

\subsection{Voluntary forest private certification}

The FSC and PEFC forest certification systems have grown significantly and have become the largest in world, with a share of about $98 \%$ of all certified forest and chain of custody (CoC) certificates (FSC and PEFC, 2013). This amounts to 417 million hectares, or $10.3 \%$ of global forests area and a share of about $28 \%$ of the total round wood production (UNECE/FAO, 2013). This approach has successfully built a new mechanism in timber product trade by requiring all traded goods to meet a balance of ecological, social and economic requirements. By creating its own rules and simultaneously increasing public awareness of certified products, forest certification initiative governs the interaction between actors in forest product trade, and replaces the role of governments which failed to sign a global convention on forestry at the Earth Summit in 1992 (Bernstein and Cashore, 1999; van Kooten et al., 2005). This private forest certification has transformed into real governance (Pattberg, 2007). Depending on their viewpoints in specific studies, forest policy analysts refer to this phenomenon using various terms, like non-state global governance (Bernstein, 2011), non-state market driven (NSMD) governance (Cashore, 2002; Cashore et al., 2007; Burns et al., 2016), non-state authority (Cashore et al., 2005), transnational (business) governance (Bartley, 2010), private forest governance (Pattberg, 2005), global forest governance (Gan et al., 2013), and global private meta-governance (Derkx and Glasbergen, 2014).

\subsection{Mandatory state certification}

At the 1998 G8 foreign ministers meeting, there was an agreement to cooperate with timberproducing countries in the development of their own measures to counter illegal logging and 
trading in illegally harvested timber (G8 Action Programme on Forests, 2002). Following this agreement, in 2003 the European Union (EU) declared the Forest Law Enforcement, Governance and Trade (FLEGT) action plan, which enabled producers from partner countries that had already signed FLEGT-voluntary partnership agreements (VPAs) to sell freely their legal products in EU territory (Brack, 2005, 2012). The agreement gave authority to partner countries to define "illegal timber" based on their own regulations, so that it acknowledged partner countries' sovereignty over their forests. To date, six countries, including Indonesia, have signed FLEGT-VPA, while nine others are in negotiations (EU FLEGT Facility, 2014). The FLEGT-VPA is seen as a more equitable type of cooperation, since it binds both producers and consumers to sell and to buy only legally harvested timber. In addition, the direct participation of consumer countries in the penalization of the sale of illegal wood-based products in their territory, as promised by the US through the Lacey Act (2008) and by European Parliament through EU Timber Regulation (2010), is expected to diminish the space for illegal timber trade (Bartley, 2014). This is what cannot be addressed by voluntary forest certification initiatives such as FSC, PEFC, ISO 14000 or other more domestic initiatives (Solutions, 2003).

The history of Indonesia-EU VPA started in 2007 while Indonesia saw that EU FLEGT could be the trigger for improving its national forest governance as well as to get international legitimacy on Indonesia wood products. A series negotiation had been done until 2011, and both parties agreed to implement VPA commitment in 2014. Two years later EU confirmed that Indonesia had fulfilled all requirements of VPA, and therefore entitle for unrestricted export into EU. Along with the negotiation, government of Indonesia has been mandating all forest logging companies and timber manufacturers to be certified under SVLK, a national timber legality assurance agreed upon in FLEGT-VPA.

\subsection{Bureaucratic politics and the power of actors}

We use bureaucratic politics theory in order to cover more broadly those actors that may be influencing policies related to forest certification at the national level. Bureaucracies are defined as "agencies that have been created by governments or other public actors with some degree or permanence and coherence and beyond formal direct control of single nation governments and that act in the international arena to pursue a policy" (Bauer e $t$ al., 2012:28). Bureaucracies are different from organizations, which are institutional arrangements built upon normative frameworks, members, and bureaucracies as administrative core institutions. They are also different from institutions, which are merely sets of principles and norms (Bauer et al., 2012). Studies on bureaucracies' behavior (e.g. Krott, 1990; Peters, 2002, Giessen \& Krott 2009, Giessen et al. 2014) reveal that although bureaucracies have a formal mandate to serve public interests, they will informally prioritize their own interests and compete with other bureaucracies for more resources, political domain and influence. To develop and direct specific policies, bureaucracies are equipped with power, which is defined as the ability to shape a programme according to own interests, even against resistance from other actors (Krott et al., 2014). According to Krott et al. (2014), power consists of three elements, namely (i) coercion, associated mostly with the ability to force an outcome, (ii) (dis-)incentives, the ability to offer (dis-)advantages to subordinate actors, and (iii) dominant information, selected information that is difficult or impossible to verify by another party. These power elements may be acquired through sanction mechanisms, transfer funds, and the expertise of bureaucracies.

Given the rise of mandatory state forest certification systems and the obstructions faced by voluntary private systems, state bureaucracies now have the following options: (i) increasing their power vis-à-vis other bureaucracies by developing own certification schemes, and (ii) reclaiming authority from private certification schemes to regulate forest management. Before this theoretical background this article will scrutinize these propositions using the following methods. 


\section{Methods}

We employed document analysis, interviews, and observations to acquire solid data to meet our objectives. First, trends in the numbers of certified forest areas and certified companies under private (FSC and LEI) and state (Ministry of Forestry) certification schemes were drawn from the website of those bodies and were placed in charts to gain an overview of each initiative's progress and to make comparisons possible. Any information from professional journals or professional mailing lists, and position papers from international organizations and associations were also considered to be valuable sources.

Second, semi-structured interviews (Halperin and Heath, 2012) to identify the main actors within this issue and their positions were conducted in Jakarta and Bogor, Indonesia, during August 2013-February 2014, and were followed by online interviews until April 2014. The interviewees were staff from the Ministry of Forestry (MoF), the Ministry of Trade (MoT), and the Indonesian Woodworking Association (ISWA), the Forest Concessionaires Association (Asosiasi Pengusaha Hutan Indonesia or APHI), the Multistakeholder Forestry Programme (MFP), FSC Indonesia, certification auditors, and environmental non-governmental organizations (ENGOs). We were also involved as observers in the respective meetings during that period to listen to each actor's ideas and to find out what expectations the actors had from others.

We treat sustainability certification and legality verification in same wave since both are quite similar in term of cost incurred and the process to go through. Some researchers (eg. Mcdermott et al., 2015; Brack, 2014) also reckon them are the same.

Actors' positions and their prospective coalitions were raised from theory of interest in environmental politics study. In analyzing actors' positions we assumed that every actor behaved rationally, meaning that actors tried to maximize their own benefit rather than to promote a general goal, like maintaining environmental sustainability and equality. To contest norm- and interest-driven is acceptable (see: Van Schaik and Schunz, 2012; Gulbrandsen, 2003) since each actor (which can be an individual, organization or state) has its own interest, adding to their effort to meet common desire. We follow expert judgment (Wibowo and Giessen, 2015) and our experiences in the field to rise up main issues and discussing them based rational behavior of actors.

\section{Results}

\subsection{Voluntary private and mandatory state certifications in figures}

Until 2014 there have been three forest certification schemes in Indonesia, namely the LEI and FSC, both of which are voluntary-private initiatives, and the PHPL (Pengelolaan Hutan Produksi/ mandatory state scheme). Forest certification assignment under the FSC was first conducted in 1998 and successfully certified three out of five assessed FMUs in Java, which was then followed by seven others within the next two years. However, all of these certificates were suspended and withdrawn in 2003 due to unsatisfactory management improvement and noncompliance with FSC standards (Muhtaman and Prasetyo, 2006). A new era of FSC standardsbased certification was introduced in 2008, when six FMUs, with a total managed area of 707,709 ha, obtained sustainable certificates (FSC, 2008). This grew to 1,089,942 ha in 2009, then dropped to 638,455 ha in 2011 , and peaked again at 2,002,710 ha in November 2014, representing the certified area of 29 FMUs (FSC, 2009, 2011, 2014). 


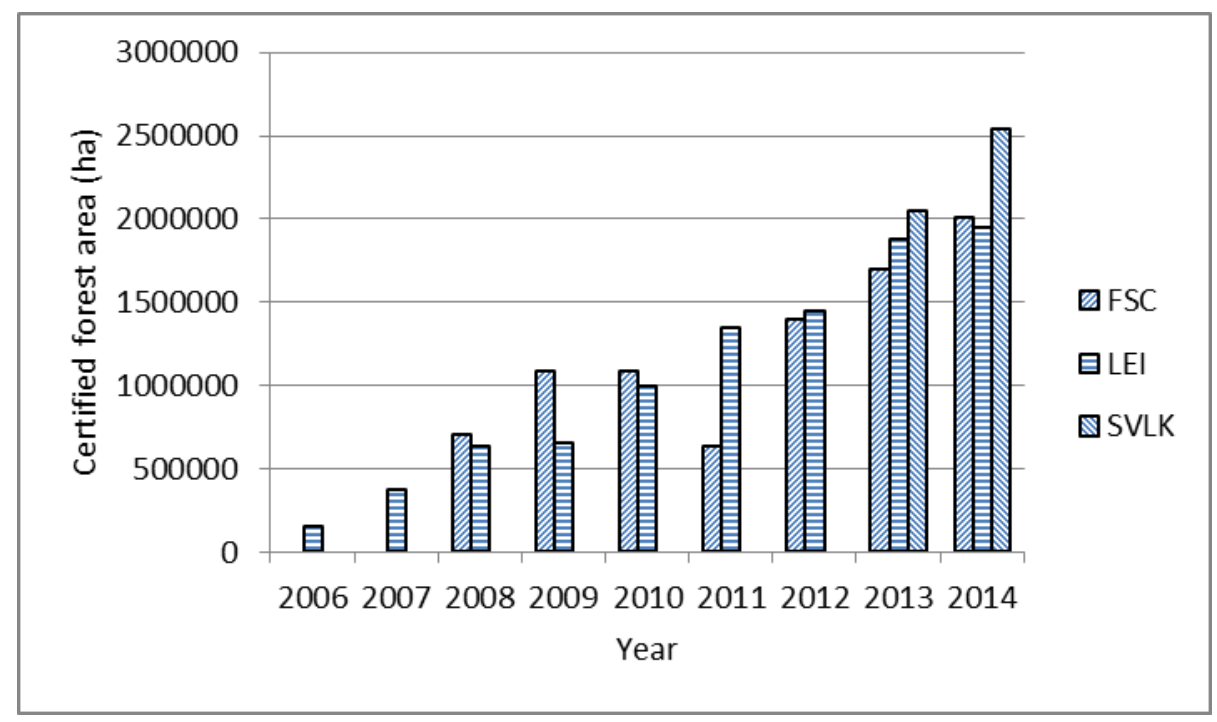

Source: FSC (various years), LEI (various years) and MoF (various years).

Figure 1. Size of certified forest area under FSC, LEI and SVLK schemes in the period 2006-2014

Similarly, the first certification process using LEI standard was also conducted in 1998, and putting PT Diamond Raya Timber who managed 90,956 ha of natural production forest as the first cooperation obtained the certificate a year later (Muhtaman and Prasetyo, 2006). Since then, there has been no serial data available to the public until the LEI released FMU and manufacture LEI certified document (LEI, 2013), which mentioned that there were $1,873,428$ ha of certifiedforests, consisting of 411,690 ha of natural production forests (22\%) from two FMUs, 1,429,055 ha of plantation forests (76\%) managed by 15 FMUs, and 32,683 ha of community forests (2\%) from 22 community groups. Furthermore, the LEI (2014) informed that the certified natural forest area had dropped about $80 \%$ within the period 2009-2014, and that the plantation forest area had increased $400 \%$ during that time.

Unlike the two previous voluntary schemes, PHPL is a mandatory state scheme enacted by the government in 2012, and effectively applied to all forest concessionaires and FMUs in 2013. The PHPL (SVLK)-certified forest area until May 2014 was 2,542,091 ha, representing an area managed by 40 FMUs (calculated from MoF, 2014). The certified forest area under the PHPL scheme was higher than those under FSC and LEl, even though the PHPL started in 2013 (Figure 1). It is likely that FSC- or LEl-certified FMUs are also certified under SVLK, since the processes to obtain such certificates are quite similar, and same certification body may carry out the late assessment. Consequently, the total certified forest area under the three schemes cannot represent the total sustainably managed forest area in Indonesia.

In respect of the chain of custody $(\mathrm{COC})$ certification, there were six companies which held LEI certificates in 2009, and one of them did not reengage with the LEl in the second round (LEI, 2014). Conversely, the number of FSC CoC certificates doubled, from 87 in 2009 to 175 in 2012, and reached 193 by November 2014 (FSC, various years). A significant number of SLKs (sertifikat legalitas kayu or timber legality certificate; a form of certificate under the SVLK) were also issued by certification bodies, as the government started to force all exporters to provide V-legal documents for their wood products. By 2013, this number reached 726 companies (MoF, 2013) or almost four times the FSC holders, and grew continuously to 894 firms in 2014 (Table 1) 
Table 1. Number of companies holding FSC, LEI and SVLK certificates

\begin{tabular}{cccc}
\hline Year & \multicolumn{3}{c}{ Number of certified companies under each scheme } \\
\cline { 2 - 4 } & FSC & LEI & SVLK \\
\hline 2009 & 87 & 6 & - \\
2010 & 136 & 6 & - \\
2011 & 161 & 6 & - \\
2012 & 175 & 6 & - \\
2013 & 188 & 6 & 726 \\
2014 & 193 & 5 & 894 \\
\hline
\end{tabular}

Source: FSC (various years), LEI (2013, 2014), MoF (2014).

\subsection{Costs of sustainable forest certification and legality verification}

The cost of forest certification and timber legality verification vary, depending on the size of forest area, investment capital, and production capacity of the company. This cost applied at first assessment to gain the certificate and at yearly surveillance within certificate's validity period. Cost component charged by certification body to the company including fee for auditors, data and information collection, field assessment, reporting fee, documentation, and security assistance for auditors if needed. For SVLK scheme the Minister of (Environment and) Forestry released the Ministry Regulation P.13/2013, which amended by P.96/2014, on the standard cost for sustainable forest management assessment and timber legality verification. It is mentioned that the total cost for legality assessment for small and medium scale-wood processing industry could reach 6.6 million IDR, and up to 28.8 and 170 million IDR for bigger industry and large forest management units, respectively. In the meantime, the cost for forest sustainability assessment is around 222280 million IDR and up to 132 million IDR for its yearly surveillance. All these costs are excluding travelling cost for auditors from Jakarta to the field. From private certification side, there is no official data on the cost of assessment and surveillance processes available for public. Pratiwi et al. (2015) reported that the costs paid by the companies for gaining FSC, LEI and PHPL-SVLK certificates are at least 31,60 , and 75 million IDR, respectively, depending on the scale of company.

\subsection{Mapping main actors and their interests}

Actors involved in forest certification in Indonesia are found along the productionconsumption chain, starting with the actors initiating certification schemes and ending with buyers in consumer countries. The following are three groups of influential actors and their roles in shaping recent construction based on their tendencies and interests.

\subsubsection{The coalition on state certification}

- The Ministry of Forestry

The Ministry of Forestry (MoF) was the main state agency responsible for establishing the national timber legality assurance system called SVLK. The SVLK installation process began in 2003, when the MoF organized some civil social organizations, i.e., Telapak, Environmental Investigation Agency, Indonesian Ecolabel Institute, and the Nature Conservancy to hold a series cross sectoral dialog in developing SVLK (MFP, 2014). SVLK, which enacted through the Minister of Forestry Regulation No P.38/2009, and up to December 2014 was already five times amended (MoF, 2011; 2012; 2013; 2014a; MoEF, 2014a), has become the core of Indonesia-EU FLEGT-VPA negotiation. The MoF tried to apply the SVLK comprehensively to all forest industry and timber manufacturers immediately, in order to maintain the credibility of the SVLK and the MoF. However, due to external pressure, the MoF (which was transformed into the Ministry of Environment and Forestry 
or MoEF in October 2014) extended the deadline for obtaining the certificates and simplified some provisions in the SVLK so that small and medium-sized enterprises could join it (see MoF, 2014b; MoEF, 2014b).

- The Ministry of Trade

The Ministry of Trade (MoT) has the mission of increasing the added value and volume of exported goods by setting up regulations to support progressive export activities. Regarding wood legality, the MoT issued a regulation on the export of forestry industrial products, whereby one group of export timber products had to have V-Legal documents in 2013, and another group had to have these in 2014 (MoT, 2012). However, since the small-scale enterprise group was not ready by the deadline, the MoT delayed the inclusion of V-Legal documents in export requirements until 2015 (MoT, 2013a), and postponed it again until 2016 (MoT, 2014a). The latest delay was taken to meet the MoT's ambition in increasing the export value of wood products by $300 \%$ within the next 5 years (Kompas, 2014). Aside from setting up regulations for ease of export, the MoT was also actively involved in SVLK negotiation with the EU and in promoting SVLK so that Indonesian furniture demand grew up by $15-20 \%$ in 2014 (MoT, 2014b).

- The Ministry of Industry

The Ministry of Industry (Mol) supports the SVLK as the way to expand overseas markets for wooden industrial products. However, the small-scale industry's unreadiness for certification and the high cost associated with it forced the Mol to ask the MoF and MoT for a delay in SVLK implementation of one year and for simplification of the SVLK verifier, mainly for wooden furniture and handicraft products (AMKRI, 2014). Previously, in March 2013, the Mol had also accommodated SMEs' scruple on SVLK and vowed to discuss a relief for them with the MoF (Agroindonesia, 2013).

- Indonesian Forest Concessionaires Association (APHI) and the Indonesian Pulp and Paper Association (APKI)

The Indonesian Forest Concessionaires Association (APHI) and the Indonesian Pulp and Paper Association (APKI), as representatives of big players in the Indonesian wood industry, actually support the SVLK, in order to improve their product image in the global market (Agrofarm, 2013). Nevertheless, since end buyers ask for FSC-certified products, local industries have to opt exclusively for FSC-certified timber in their production line. Consequently, SVLK-certified intermediary goods cannot be sold locally, let alone in the global market (The Jakarta Post, 2014b) and the producers have to bear a double cost to tackle the problem (Hutan Indonesia, 2013). Since the SVLK is designed to comply with an agreement with the EU (Pohnan and Stone, 2013), the policy of making the SVLK obligatory for all logging companies and wood-processing industries is considered detrimental to local businesses and industries not oriented towards the European market. Both associations have already asked the government to open more local markets for SVLK-certified products and to promote the SVLK more broadly.

- Indonesian Sawmill and Woodworking Association (ISWA), Association of Indonesian Furniture and Crafts Producers (Asmindo) and small tree growers

Small wood industries and small tree growers support the SVLK, associating it with better market access in Europe and other countries (The Jakarta Post, 2014a; Agroobserver, 2015). However, they warn that the requirements for small industries should be simpler than those for big ones, since small tree growers work in private land parcels, and they do their own planting and harvesting (Agroindonesia, 2014). They also may change the use of the land or sell it in a traditional way, without permits from anybody else. Hence, they don't have to "formalise" their business by means of legal permits, taxation, environmental assessment and other administrative documents, which are costly (Obidzinski et al., 2014). 


\section{- European Union (EU)}

EU efforts to halt illegal timber circulation inside and outside the region are evident in the two main regulations under the FLEGT Action Plan, namely the FLEGT-VPA and the EU Timber Regulation (EUTR). The EUTR can be seen as an economic tool to strengthen the position of European timber against its competitors, since any wood products to be exported to Europe have to pass a due diligence investigation by operators (van Heeswijk and Turnhout, 2013). In contrast, the FLEGT-VPA, which includes a timber legality assurance system (TLAS) from the producer country, ignores the due diligence process for FLEGT-licensed products. In the case of the SVLK, both Indonesia and EU parties signed and ratified the VPA in 2014 and acknowledged SVLK as Indonesian TLAS. However, the EU support for the SVLK cannot be seen simply as a passport of sorts for Indonesia's wood products entering EU territory, since it could be suspended once a SVLK-licensed product is discredited (Hawin et al., 2010).

- The Multistakeholder Forestry Programme (MFP) and Kehati Foundation

The MFP is a UK-funded program that assists the MoF in developing and promoting the SVLK, and in helping FMUs and small enterprises to obtain SVLK-based certificates through its coaching program (Raharjo, 2013). Together with the MoF, the MFP was engaged in SVLK negotiations with the EU. The MFP also strongly encourages the government of Indonesia to implement SVLK and rejects its delay, which the industry sector has requested often. The Kehati foundation, on the other hand, is a national funding agency that supports activities related to biodiversity conservation. Both the MFP and Kehati reckon that SVLK is in line and could be the way to succeed REDD+ program (Dharmawan et al., 2012).

\subsubsection{The coalition on private certification}

Most leading ENGOs support private certification initiatives to achieve better forest governance. These include: the Borneo Initiative, the Tropical Forest Foundation and the WWFGlobal Forest and Trade Network, which work on the LEI and FSC schemes, and Greenpeace and the Nature Conservancy, which work on the FSC (Greenpeace, 2014). These ENGOs promote schemes they support and decline others for reasons of lack of accountability, poor sustainability standards and double costs consequence, among others. A network of ten ENGOs, called the Anti Forest-Mafia Coalition has criticized the SVLK, judging it to be flawed and a new form of "green washing" illegal timber (Anti Forest-Mafia Coalition, 2014). However, their members also help small enterprises to obtain SVLK certificates (Antara, 2015). Some of them publish SVLK's weaknesses repeatedly, even though they do not show their partiality to private forest certification schemes.

\subsubsection{Other actors}

\section{- Certification Bodies}

Currently there are 18, 2 and 4 certification bodies working on the SVLK, the FSC and the LEI, respectively (MoF, 2013; various sources) where some of them work with more than one scheme. Certification bodies have the right to issue certificates of sustainable forest management practice or chain of custody and the right to withdraw such a certificate during an annual inspection if the holders no longer comply with the standards of a given certification scheme. Due to a disproportional ratio between the certification body and number of areas/companies to be certified, the certification cost is increasing and is becoming unaffordable for small industries (Obidzinski et al., 2014). The principle of transparency in the audit process makes it possible for one certification body to know what other bodies do, what auditor works for which body, and the certification fees applied to particular audit process. Furthermore, once a certification body has conducted an audit, it has to announce the plan or the results on determined website so that it is 
open to input from independent observers, NGOs, and other stakeholders. The transparency principle allows the work of the auditor to be criticized (see also Maletz and Tysiatchniouk, 2009); hence, the certificates already issued may be withdrawn for many reasons. Frequently revocations of certificates will affect not only the certification body, but also the certification scheme they use.

- International buyers

After FLEGT-VPA signation, timber certified for sustainability and timber certified for legality compete for consumer demand for eco-friendly products. International buyers, as the end users of such products, will choose between state-based certified products and private-based certified woods. Accordingly, it is important to provide potential buyers with appropriate information on own products' superiority (Cashore, 2002). Potts et al. (2010) point out that major retailers in North America have decided to choose forest products derived from sustainable sources, whereas EU countries require importers, manufacturers, and retailers to have chain of custody (CoC) certification that clarifies the origin of their timber. Cai and Aguilar (2013) compiled 19 studies on consumer's willingness-to-pay for certified wood products, and found that $1-39 \%$ of consumers were willing to pay premium prices for these products, no matter what kind of label it had. This means that the number of consumers willing to pay a higher price for certified products was less than that of those unwilling to pay. Consumers do not care whether products are certified or not, let alone whether the certification initiatives are private or governmental.

We summarize actors' major power under each power element type (Table 2) to make a way in predicting their fragmentation and future possibly alliance. The power elements are used rationally, depends on actor interest; and not always used or appeared in their action although they are able to do so.

Table 2. Major power element of powerful actor

\begin{tabular}{|c|c|c|}
\hline Type of power element & Powerful actor & Strategic power \\
\hline Coercion & $\begin{array}{l}\text { Ministry of Environment and } \\
\text { Forestry } \\
\text { Ministry of Trade } \\
\text { EU }\end{array}$ & $\begin{array}{l}\text { Permit for forest management unit } \\
\text { and industries } \\
\text { Permit to export wooden goods } \\
\text { FLEGT licencing for wood products to } \\
\text { enter EU }\end{array}$ \\
\hline Dis(incentive) & $\begin{array}{l}\text { Ministry of Environment and } \\
\text { Forestry } \\
\text { International buyers }\end{array}$ & $\begin{array}{l}\text { Providing financial support for } \\
\text { legality verification } \\
\text { Creating demands for certified } \\
\text { wooden goods }\end{array}$ \\
\hline Dominant information & $\begin{array}{l}\text { Ministry of Environment and } \\
\text { Forestry } \\
\text { Ministry of Industry } \\
\text { Private certification owners } \\
\text { MFP and Kehati Foundation } \\
\text { Environmental NGOs } \\
\text { Certification body }\end{array}$ & $\begin{array}{l}\text { Revising and evaluating SVLK } \\
\text { standard } \\
\text { Holding information on industry } \\
\text { competitiveness and healthy } \\
\text { Good image } \\
\text { Negotiation experts and facilitators } \\
\text { International influencers and opinion } \\
\text { makers for environmental issues } \\
\text { Issuing sustainability and legality } \\
\text { certificates }\end{array}$ \\
\hline
\end{tabular}

\section{Discussion}

\subsection{Fragmented certification schemes and their alliances}


Based on policy-making authority, Cashore (2002) divides environmental governance into three categories, namely, "non-state market driven governance", characterized by the lack of government involvement in the policy-making process; "shared private/public governance", in which policy-making is shared with the government; and "traditional governance", where policymaking authority belongs fully with the government. Gulbrandsen (2004) uses the term "private governance" to refer to NSMD governance, and "public governance" (meaning state governance) for traditional governance. Gulbrandsen (2004) adds hybrid private-public governance to denote industry-dominated involvement in mixed private and public governance. Following categorization by Cashore (2002) and Gulbrandsen (2004) we found that there are now four clusters of forest certification governance present in Indonesia, namely environmental-private governance, hybrid private-public governance, producer-private governance, and state governance, with the FSC, the LEI, the IFFC and the SVLK representing each scheme, respectively (Table 3). It is important to note that the cluster is not within the strict boundary. Each actor may cooperate with other parties in other groups if it deemed to be gainful.

Table 3. Cluster of forest certification governance in Indonesia

\begin{tabular}{|c|c|c|c|c|}
\hline Key features & $\begin{array}{l}\text { Environmental- } \\
\text { private } \\
\text { governance (FSC) }\end{array}$ & $\begin{array}{l}\text { Hybrid private- } \\
\text { public } \\
\text { governance (LEI) }\end{array}$ & $\begin{array}{l}\text { Producer-private } \\
\text { governance } \\
\text { (PEFC/IFCC) }\end{array}$ & $\begin{array}{l}\text { State } \\
\text { governance } \\
\text { (SVLK) } \\
\end{array}$ \\
\hline $\begin{array}{l}\text { Rule maker } \\
\text { State } \\
\text { involvement }\end{array}$ & $\begin{array}{l}\text { Environmentalists } \\
\text { No }\end{array}$ & $\begin{array}{l}\text { Academics } \\
\text { Partially }\end{array}$ & $\begin{array}{l}\text { Land owners } \\
\text { Limited }\end{array}$ & $\begin{array}{l}\text { Government } \\
\text { Full }\end{array}$ \\
\hline $\begin{array}{l}\text { Major } \\
\text { supporting actor }\end{array}$ & ENGOs & None & $\begin{array}{l}\text { Forest and } \\
\text { wood-based } \\
\text { Industry }\end{array}$ & Government \\
\hline $\begin{array}{l}\text { Coverage } \\
\text { territory }\end{array}$ & International & $\begin{array}{l}\text { Mainly in } \\
\text { Indonesia }\end{array}$ & International & $\begin{array}{l}\text { Mainly in } \\
\text { Indonesia }\end{array}$ \\
\hline Auditor & Third party & Third party & Third party & Third party \\
\hline $\begin{array}{l}\text { Public } \\
\text { examination }\end{array}$ & Yes & Yes & Yes & Yes \\
\hline $\begin{array}{l}\text { Certificate } \\
\text { acceptability }\end{array}$ & International & National & International & EU and National \\
\hline Brand image & Strong & Weak & Quite strong & Weak \\
\hline $\begin{array}{l}\text { Industry } \\
\text { participation }\end{array}$ & Voluntary & Voluntary & Voluntary & Mandatory \\
\hline $\begin{array}{l}\text { Influential actor } \\
\text { to succeed }\end{array}$ & $\begin{array}{l}\text { Business to } \\
\text { business }\end{array}$ & $\begin{array}{l}\text { Business to } \\
\text { business }\end{array}$ & $\begin{array}{l}\text { Business to } \\
\text { business }\end{array}$ & $\begin{array}{l}\text { Government to } \\
\text { government and } \\
\text { business to } \\
\text { business }\end{array}$ \\
\hline $\begin{array}{l}\text { Law } \\
\text { enforcement }\end{array}$ & No & No & No & Yes \\
\hline
\end{tabular}

Except for the LEl, the other three schemes have their supporting actors who promote the schemes' excellence. Due to the lack of capital, human resource and interest affinity, and therefore we argue that the hybrid private-public government will disappear, and the FMUs and wood industries will make alliances with the government to support traditional forest governance. The IFFC could join the SVLK, since the IFFC originally devoted for forest owners and forest managers. Consequently, there will be only two certification schemes competing for authority in 
the future, namely, the pro-environment and pro-business schemes. The first scheme is represented by the FSC and would be supported by ENGOs, academics and the pro-environmental community, and the LEI, since LEl already signed a joint certification protocol with the FSC. With this collaboration, the FSC has a local partner to introduce its more local-value adapted scheme, and the LEI could maintain its presence in the forest certification field. The increasing number and size of certified forests under FSC indicates the strengthening of this scheme cluster. Conversely, the pro-business scheme consists of SVLK and PEFC will mutually reinforce and possible to make joint recognition for effective certification process, and wider market access. This scheme is supported by the government, landowners, and FMUs. Due to the wider stakeholder involvement and its mandatory nature, this scheme seems to flourish continuously, as indicated by its progress in the year of early implementation.

Through this process, the forest certification regime becomes less complex, since national political processes replace and reduce the international element of international forest regimes, and standard of these schemes may less different (McDermott et al., 2008). Industrial groups, as the users of the certification scheme, have to engage with the SVLK to maintain their business continuity and to enter the market, and only add the FSC to improve their reputation (Wibowo et al., 2015). However, the solidity of this pattern will become more stable under the following conditions. First, if the government of Indonesia promotes the SVLK and its acceptance in other consumer countries, hence industries will need no other certification scheme when exporting their products to such countries. Second, if the government preserves the SVLK as a reputable certification scheme by publishing data having to do with the ways in which the SVLK contributes to the deforestation rate reduction and to the enhancements of society and ecology. Third, if there are fewer or no objections from other stakeholders about the performance of industries that are SVLK-certified, indicating that these companies do business in legal and sustainable ways.

\subsection{Obligation and fees as bureaucratic power strategy under SVLK}

By making the SVLK mandatory for all FMUs and timber manufacturers, the MoF may gain at least three benefits. First, it could increase its presence in downstream industry circles by financing the first SVLK-certification process for small enterprises (Neraca, 2014). Through this assistance, the MoF would gain power over small enterprises, which in the past have belonged in the domain of the Mol. Second, compelling the enterprises to choose SVLK only or either SVLK and private schemes. The high cost of legality verification and forest certification is the main factor obstructing companies to engage with those processes (Tacconi, 2007; Obidzinski et al., 2014), although it does not always correspond to its benefits. Pratiwi (2015) shows that only around $24 \%$ of industry, forest companies and their related associations state that the cost of SVLK-certification is worth its benefits, while only $26 \%$ of them acknowledge that they always receive premium prices from their certified products. The gap between the cost and the benefits resulting from certification process forces business actors to be realistic in choosing appropriate certification scheme. This selection strongly depends on their market target and value of the exported products (see Fikru, 2014). If combination of mandatory and voluntary certification costs were higher than the profit, business tended to choose only the SVLK for their products. Third, as consequence of the previous point, the SVLK may be better known and legitimate in domestic and overseas markets. With only around $10 \%$ share of Indonesian timber export value goes to Europe (MoF, 2014c), the obligation to put Vlegal sign (sign for SVLK-certified products) in all exported timber products will make SVLK better known in other major destination countries like China, Japan, and South Korea.

\subsection{Privileging large-scale industries over smallholders}

It is widely known that small scale wood industries and tree growers are characterized by limited administration records, production-by-demand orientation, simple management practices, 
and have less capacity to follow market dynamics (Nurrochmat, 2004). Obidzinski et al. (2014) point out the major challenges to small and medium enterprises (SMEs) in obtaining SVLK-based certificates, namely: business legality status; limited supply of legal timber; small profit margins spread over a long value chain; high certification costs; and small volume and unpredictable harvest times. Under these circumstances it is hard for them to obtain wood legality certificates (SLK; SVLK-based certificate) even if the trees grown in home yards and their transfers to processing industries are truly legal. The lack of verification bodies and the limited financial support by government are other obstacles for the engagement of small industries in SVLK schemes (Obidzinski et al., 2014). Hence, the policy of implementing SVLK certification in all wood industries is thought to be a simple way to increase export value to European markets by large industries, at the expense of SMEs. On the other hand, the export ban policy for non-certified industry will cut USD 900 million in annual income for SMEs, which amounts to 30\% of the total wood export value to non-European markets, excluding pulp and paper (Agroindonesia, 2014). To avoid this loss, the MoT has postponed the implementation of such a policy twice already.

It seems that the MoT places foreign market access and trade performance as the top priority, followed by the survival of large scale industries, wood legality, the subsistence of SMEs, and facility of sales for small tree growers. This policy might limit the circulation of illegal wood, facilitate the supervision of the industry and increase the trust in the SVLK; but it suppresses small and very locally-oriented industries, and creates a disincentive for small tree growers. Small tree growers face legal consequences and may even be found guilty of criminal charges when they harvest and transfer wood from their garden to small wood industries. A more local and adaptive policy that is able to distinguish illegal timber and -incomplete documented timber -like a conformity declaration already being considered-is needed for this kind of business (Kemitraan, 2014), in order to avoid negative social consequences.

\section{Conclusions}

The Ministry of (Environment and) Forestry was under political pressure from other bureaucracies, and was asked to improve its performance in generating income from forest areas. The Ministry then used its authority to govern forest product circulation and trade in domestic and global markets through the forest certification initiative. This program has at least four goals: to show the public its efforts in reducing illegal logging and the deforestation rate; to restore the forestry sector as the main contributor to state income, as it was in 1990s; to preserve its existence by obliging all FMUs and wood industries to be certified by such a scheme and to become the agency in charge of the Indonesia-EU agreement on FLEGT; and to increase the state sovereignty over forests, by being the institution to decide on the legality of timber. The involvement of the MoF in the forest certification arrangement indicates that private governance is not the final and stable form of this regime, as is argued by some scholars (e.g. Hackett, 2013; Overdevest and Zeitlin, 2014). In addition, the MoF uses its authority to reclaim authority over private actors (see also Giessen et al., 2016). The MoF is likely to succeed, due to the ease of implementation and simple standards of the scheme, which also account for the relatively inexpensive cost of certification assessment fee, in comparison to its competitors (Pratiwi et al., 2015; Maryudi, 2016). Furthermore, the mandatory nature of the SVLK means it has fixed a downstream market, i.e., FMUs and wood industries, whilst upstream it can profit from an educated market that has already been created by private governance. In this case, the state governance seems to be the free rider.

A remaining question needs to answer by both governances is whether their presence is able to reduce forest loss and to sustain forest management. Since $18 \%$ of deforested area in Indonesia is open land and the rest is designated for development purposes (Kissinger et al., 2012), we argue that the certification regime will be unable to reduce forest conversions. Most of the forest 
conversions were planned and allowed by the government, and that is why these, together with other "deforested areas", were not included in the calculation of the deforestation rate (Bellot et al., 2014). In addition, the sustainability criteria of certification regimes do not reflect the fact that small tree growers do clear-cutting when they need cash for unforeseen expenses, like a marriage or educational costs, and that they do not replant their gardens. Hence, legality verification and sustainability certification are disconnected from forest (land) management performed by small tree growers or forest companies. Based on these points, we argue that the certification regime and legality verification are merely instruments to govern timber trade (indicated as transnational business governance by Lesniewska and McDermott, 2014) at the expense of small and traditional tree growers, rather than an effort to secure remaining tropical forests.

\section{References}

\section{Literature}

Bartley, T. (2007). How foundations shape social movements: The construction of an organizational field and the rise of forest certification. Social Problems, 54(3), 229-255.

Bartley, T. (2010). Transnational private regulation in practice: The limits of forest and labor standards certification in Indonesia. Business and Politics, 12(3), Article 7. DOI: 10.2202/1469-3569.1321.

Bartley, T. (2014). Transnational governance and the re-centered state: Sustainability or legality?. Regulation \& Governance, 8(1), 93-109.

Bauer, S., Andresen, S., \& Biermann, F. (2012). International bureaucracies. In: Biermann, F., \& Pattberg, P. H. (Eds.). Global environmental governance reconsidered. MIT Press. p.27-44.

Bell, S., \& Hindmoor, A. (2012). Governance without government? The case of the Forest Stewardship Council. Public Administration, 90(1), 144-159.

Bellot, F.F., Bertram, M., Navratil, P., Siegert, F. \& Dotzauer, H. (2014). The high-resolution global map of 21st-century forest cover change from the University of Maryland ('Hansen Map') is hugely overestimating deforestation in Indonesia. Available at: http://forclime.org/images/ documents/FORCLIMEOverestimation\%20of\%20Deforestation.pdf. [Accessed 14 November 2014].

Bernstein, S., \& Cashore, B. (1999). World trends and Canadian forest policy: trade, international institutions, consumers and transnational environmentalism. Forestry Chronicle, 75(1), 3438.

Bernstein, S. (2011). Legitimacy in intergovernmental and non-state global governance. Review of International Political Economy, 18(1), 17-51.

Blackman, A., Raimondi, A., \& Cubbage, F. (2014). Does forest certification in developing countries have environmental benefits? Insights from Mexican Corrective Action Requests. Insights from Mexican Corrective Action Requests (March 31, 2014). Resources for the Future Discussion Paper, (14-06).

Boström, M. (2003). How state-dependent is a non-state-driven rule-making project? The case of forest certification in Sweden. Journal of environmental policy \& planning, 5(2), 165-180.

Brack, D. (2005). Controlling illegal logging and the trade in illegally harvested timber: the EU's Forest Law Enforcement, Governance and Trade Initiative. Review of European community \& international environmental law, 14(1), 28-38.

Brack, D. (2012). Excluding illegal timber and improving forest governance: The European Union's Forest Law Enforcement, Governance and Trade initiative. In: High-Value Natural Resources and Peacebuilding, ed: P. Lujala and S. A. Rustad. London: Earthscan. p. 211-220. 
Brack, D. (2014). Promoting legal and sustainable timber: using public procurement policy. Chatham House for the Royal Institute of International Affairs.

Burns, S., Yapura, P., Giessen, L. (2016). State actors and international forest certification policy: coalitions behind FSC and PEFC in federal Argentina. Land Use Policy, 52, 23-29.

Cai, Z., \& Aguilar, F. X. (2013). Meta-analysis of consumer's willingness-to-pay premiums for certified wood products. Journal of Forest Economics, 19(1), 15-31.

Cashore, B. (2002). Legitimacy and the privatization of environmental governance: How non- state market-driven (NSMD) governance systems gain rule-making authority. Governance, 15(4), 503-529.

Cashore, B., Auld, G., \& Newsom, D. (2005). Governing through markets: Forest certification and the emergence of non-state authority. Journal of Environmental Planning and Management, 48(4), 619-624.

Cashore, B., Egan, E., Auld, G., \& Newsom, D. (2007). Revising theories of nonstate market-driven (NSMD) governance: lessons from the Finnish forest certification experience. Global Environmental Politics, 7(1), 1-44.

Derkx, B., \& Glasbergen, P. (2014). Elaborating global private meta-governance: An inventory in the realm of voluntary sustainability standards. Global Environmental Change, 27, 41-50.

Dharmawan, A. H., Nugroho, B., Kartodihardjo, H., Kolopaking, L. M., \& Boer, R. (2012). SVLK, Jalan Menuju REDD+. Forest Governance and Multistakeholder Forestry Programme, Ministry of Forestry Indonesia-UK Department for International Development.

Durst, P. B., McKenzie, P. J., Brown, C. L., \& Appanah, S. (2006). Challenges facing certification and eco-labelling of forest products in developing countries. International Forestry Review, 8(2), 193-200. DOI: 10.1505/ifor.8.2.193.

Espach, R. (2006). When is sustainable forestry sustainable? The forest stewardship council in Argentina and Brazil. Global Environmental Politics, 6(2), 55-84.

Fikru, M. G. (2014). International certification in developing countries: The role of internal and external institutional pressure. Journal of environmental management, 144, 286-296.

Gale, F., \& Haward, M. (2011). Global commodity governance: state responses to sustainable forest and fisheries certification. Palgrave Macmillan.

Gan, J., Cashore, B., \& Stone, M. W. (2013). Impacts of the Lacey Act Amendment and the Voluntary Partnership Agreements on illegal logging: implications for global forest governance. Journal of Natural Resources Policy Research, 5(4), 209-226.

Giessen, L., \& Krott, M. (2009). Forestry joining integrated programmes? A question of willingness, ability and opportunities. Allgemeine Forst-und Jagdzeitung, 180(5/6), 94-100.

Giessen L., Burns S., Sahide A. M. K., Wibowo, A. (2016). From governance to government: The key role of state bureaucracies in forest and agricultural certification. Policy and Society, 35 (1), 71-89.

Gulbrandsen, L. (2003). The evolving forest regime and domestic actors: strategic or normative adaptation?. Environmental Politics, 12(2), 95-114.

Gulbrandsen, L. H. (2004). Overlapping public and private governance: Can forest certification fill the gaps in the global forest regime? Global Environmental Politics, 4(2), 75-99.

Gulbrandsen, L. H. (2014). Dynamic governance interactions: Evolutionary effects of state responses to non-state certification programs. Regulation \& Governance, 8, 74-92.

Hackett, R. (2013). From government to governance? Forest certification and crisis displacement in Ontario, Canada. Journal of Rural Studies, 30, 120-129.

Halperin, S., \& Heath, O. (2012). Political research: methods and practical skills. Oxford University Press.

Hawin, M., Nurhayati, I. \& Antoni, V. (2010). Analisis hukum teks Voluntary Partnership Agreement antara Indonesia dan Eropa. Jakarta: Forest Governance and Multistakeholder Forestry Programme. 
Hutan Indonesia. (2013). Mengejar Tenggat Sertifikasi PHPL Mandatory. Hutan Indonesia, III, 2627.

Hysing, E. (2011). Transnational environmental governance: the emergence and effects of the certification of forests and fisheries by Lars H. Gulbrandsen (Cheltenham, UK: Edward Elgar). Environment and Planning. C, Government and Policy, 29(3), 567-568.

Kissinger, G., Herold, M., \& De Sy, V. (2012). Drivers of deforestation and forest degradation: a synthesis report for REDD+ policymakers. Vancouver: Lexeme Consulting.

Krott, M. (1990). Öffentliche Verwaltung im Umweltschutz. Ergebnisse einer behördenorientierten Policy-Analyse am Beispiel Waldschutz. Wien: W. Braumüller Verlag.

Krott, M., Bader, A., Schusser, C., Devkota, R., Maryudi, A., Giessen, L., \& Aurenhammer, H. (2014). Actor-centred power: The driving force in decentralised community based forest governance. Forest Policy and Economics, 49, 34-42.

Lesniewska, F., \& McDermott, C. L. (2014). FLEGT VPAs: Laying a pathway to sustainability via legality lessons from Ghana and Indonesia. Forest policy and economics, 48, 16-23.

Malets, O. (2015). When transnational standards hit the ground: Domestic regulations, compliance assessment and forest certification in Russia. Journal of Environmental Policy \& Planning, 17(3), 332-359.

Maletz, O. \& Tysiatchniouk M. (2009). The Effect of Expertise on the Quality of Forest Standards Implementation: The Case of FSC Forest Certification in Russia. Forest Policy and Economics, $11(5-6): 422-428$

Maryudi, A. (2006). Sertifikasi Hutan: Instrumen Baru Dalam Kebijakan Kehutanan. Rimba Kalimantan, 11(1), 27-35.

Maryudi, A. (2016). Choosing timber legality verification as a policy instrument to combat illegal logging in Indonesia. Forest Policy and Economics, 68, pp.99-104.

Maryudi, A. (2009). Forest certification for community-based forest management in Indonesia: Does LEI provide a credible option?. Hayama-mati (Kanagawa-ken): Institute for Global Environmental Strategies, Forest Conservation, Livelihoods, and Rights Project.

McDermott, C. L., Noah, E., \& Cashore, B. (2008). Differences that 'matter'? A framework for comparing environmental certification standards and government policies. Journal of Environmental Policy and Planning, 10(1), 47-70.

McDermott, C. L. (2014). REDDuced: From sustainability to legality to units of carbon-The search for common interests in international forest governance. Environmental Science and Policy, $35,12-19$.

McDermott, C. L., Irland, L. C., \& Pacheco, P. (2015). Forest certification and legality initiatives in the Brazilian Amazon: Lessons for effective and equitable forest governance. Forest Policy and Economics, 50, 134-142.

Muhtaman, D. R., \& Prasetyo, F. A. (2006). Forest certification in Indonesia. In: Cashore, B. et al. (eds). Confronting sustainability: Forest certification in developing and transitioning countries. Yale University Faculty of Environmental Studies Publication Series, 33-68.

Nurrochmat, D. R. (2004). Social forestry to alleviate poverty: concepts and experiences in Indonesia. In: Poverty Alleviation: Concepts and Experiences: Focused on Indonesian Cases. Cuvillier. Verlag Göttingen. p. 39-44

Nurrochmat, D. R., Dharmawan, A. H., Obidzinski, K., Dermawan, A., \& Erbaugh, J. T. (2016). Contesting national and international forest regimes: Case of timber legality certification for community forests in Central Java, Indonesia. Forest Policy and Economics, 68, 54-64.

Obidzinski, K., Dermawan, A., Andrianto, A., Komarudin, H., \& Hernawan, D. (2014). The timber legality verification system and the voluntary partnership agreement (VPA) in Indonesia: Challenges for the small-scale forestry sector. Forest Policy and Economics, 48, 24-32. Overdevest, C., \& Zeitlin, J. (2014). Assembling an experimentalist regime: Transnational governance interactions in the forest sector. Regulation \& governance, 8, 22-48. 
Overdevest, C., \& Zeitlin, J. (2014). Assembling an experimentalist regime: Transnational governance interactions in the forest sector. Regulation \& governance, 8, 22-48.

Pattberg, P. H. (2005). The Forest Stewardship Council: Risk and potential of private forest governance. The Journal of Environment \& Development, 14(3), 356-374.

Pattberg, P. H. (2007). Private institutions and global governance: the new politics of environmental sustainability. Edward Elgar Pub.

Peters, G. (2002). Politics of Bureaucracy. Routledge.

Pohnan, E., \& Stone, M. (2013). Can legality verification combat illegal logging in Indonesia? Strategic insights for policy makers and advocates. Issues and Options Brief. IUFRO Task Force on Forest Governance, 16 November 2013.

Potts, J., van Der Meer, J., \& Daitchman, J. (2010). The state of sustainability initiatives review 2010: Sustainability and transparency.

Pratiwi, S. (2015). Comparing forest certification and legality verification system and explaining stakeholder preferences in Indonesia. Master Thesis. University of Goettingen.

Pratiwi, S., Wibowo, A., \& Giessen, L. (2015). Third-Party Certification of Forest Management In Indonesia: Analysing Stakeholders' Recognition and Preferences. Jurnal Manajemen Hutan Tropika, 21(2), 65-75.

Raharjo, D. (2013). Laporan Akhir Multistakeholder Forestry Programme (MFP2). Ministry of Forestry of Republic of Indonesia, KEHATI, UKAID. Jakarta. pp. 109.

Sahide, A., Burns, S., Wibowo, A., Nurrochmat, D.R., Giessen, L. (2015). Towards state hegemony over agricultural certification: from voluntary private to mandatory state regimes on palm oil in Indonesia. Jurnal Manajemen Hutan Tropika, 21 (3), 162-171.

Sikor, T. (Ed.). (2013). Public and private in natural resource governance: a false dichotomy? Routledge.

Solutions, S. G. T. (2003). Establishing the foundation for sustainable forest management in Africa: Legal origin of timber as a step towards sustainable forest management. SGS, Geneva. Available at: http://siteresources.worldbank.org/EXTFORESTS/Resources/985784-1217874 560960/AFRLegalOrigin.pdf [Accessed 10 January 2015].

Tacconi, L. (2007). Verification and certification of forest products and illegal logging in Indonesia. In: Tacconi, L. (Editor). Illegal logging: law enforcement, livelihoods and the timber trade. London: Earthscan. p. 251-274.

Tosun, J. (2012). Forest certification in Europe: Exploring the determinants of cross-country variation. Marmara Journal of European Studies, 20(1), 177-197.

UNECE (United Nations. Economic Commission for Europe)/FAO (Food and Agriculture Organization (2013). Forest Products Annual Market Review, 2012-2013. New York and Geneva, United Nations, Geneva Timber and Forest Study Paper, 33.

van Heeswijk, L., \& Turnhout, E. (2013). The discursive structure of FLEGT (Forest Law Enforcement, Governance and Trade): The negotiation and interpretation of legality in the $\mathrm{EU}$ and Indonesia. Forest Policy and Economics, 32, 6-13.

van Kooten, G. C., Nelson, H. W., \& Vertinsky, I. (2005). Certification of sustainable forest management practices: a global perspective on why countries certify. Forest Policy and Economics, 7(6), 857-867.

van Schaik, L., \& Schunz, S. (2012). Explaining EU Activism and Impact in Global Climate Politics: Is the Union a Norm-or Interest-Driven Actor?. JCMS: Journal of Common Market Studies, 50(1), 169-186.

Wibowo A., Sahide M.A., Pratiwi S., Dharmawan B. \& Giessen L. (2015). Ragam Skema Sertifikasi Hutan Global dan Opsi Transformasinya di Indonesia. Risalah Kebijakan Pertanian dan Lingkungan. 2 (1), 1-8.

Wibowo, A., \& Giessen, L. (2015). Actor Positions on Primary and Secondary International Forestrelated Issues Relevant in Indonesia. Journal of Sustainable Development, 8(3), 10-27. 
Wiersum, K. F., \& Elands, B. H. (2013). Opinions on legality principles considered in the FLEGT/VPA policy in Ghana and Indonesia. Forest Policy and Economics, 32, 14-22.

\section{Empirical materials and regulations cited}

Agrofarm (2013). Tidak ada insentif, SVLK bebani APHI. Available at: http://www.agrofarm.co.id /m/kehutanan/121/tidak-ada-insentif-svlk-bebani-aphi/. [Accessed 14 January 2015].

Agroindonesia (2013). Komitmen Indonesia tetap terjaga. Available at: http://agroindonesia.co.id /2013/03/19/komitmen-indonesia-tetap-terjaga [Accessed 14 January 2015].

Agroindonesia (2014). Cukup selipkan satu pasal. http://agroindonesia.co.id/2014/01/cukupselipkan-satu-pasal/ [Accessed 14 January 2015].

Agroobserver (2015). ISWA: Pemerintah diharap jangan hambat industri barecore dari sengon. Available at: http://agroobserver.com/iswa-pemerintah-diharap-jangan-hambat-industri barecore-dari-sengon/ [Accessed 14 January 2015].

AMKRI (Asosiasi Mebel dan Kerajinan Indonesia) (2014). Menteri Perindustrian Saleh Husin setujui penundaan pemberlakuan sistem verifikasi legalitas kayu (SVLK). Available at: http://www.amkri.org/berita/menteri-perindustrian-saleh-husin-setujui-penundaanpemberlakuan-sistem-verifikasi-legalitas-kayu-(svlk)--337.php [Accessed 14 January 2015].

Antara (2015). WWF-Asmindo bantu industri kecil kehutanan peroleh SVLK. Available at: http://www.antarajatim.com/lihat3/berita/149907/wwf-asmindo-bantu-industri-kecilkehutanan-peroleh-svlk [Accessed 20 February 2015].

Anti Forest-Mafia Coalition (2014). SVLK flawed: An independent evaluation of Indonesia's timber legality certification system. Available at: http://eyesontheforest.or.id/attach/Anti\% 20Forest\%20Mafia\%20Coalition\%20\%2818Mar14\%29\%20SVLK\%20Flawed\%20FINAL.pdf [Accessed 14 January 2015].

EU FLEGT Facility (2014). VPA countries. Available at: http://www.euflegt.efi.int/vpa-countries [Accessed 14 June 2014].

FSC (Forest Stewardship Council) (2008, 2009, 2011, 2014). Global FSC certificates: type and distribution. Available at: https://ic.fsc.org/facts-figures.19.html [Accessed 14 Mach 2015].

FSC (Forest Stewardship Council) (2010). FSC Directive on FSC Forest Management Evaluations. Available at: https://www.scsglobalservices.com/files/standards/FSC-DIR-20-007_EN.pdf. [Accessed 14 June 2014].

FSC (Forest Stewardship Council) \& PEFC (Programme for the Endorsement of Forest Certification) (2013). Joint statement by the Forest Stewardship Council (FSC) and the Programme for the Endorsement of Forest Certification (PEFC) recommending ISO member to vote against the new work item proposal Chain of Custody of Forest Based Products-Requirements. Available at: http://www.pefc.org/images/documents/external/Joint_StatementFSC_PEFC_July_8 _2013.pdf [Accessed 12 June 2014].

FSC (Forest Stewardship Council) (2014). FSC harmonised certification bodies' Forest Stewardship Standard for the Republic of Indonesia. Available at: http://www.scsglobalservices.com/ files/standards/fsc-std-idn-01-01-2013_indonesianatural_plantations_and_slimf.pdf [Accessed 14 December 2014].

G8 Action Programme on Forests (2002). G8 action programme on forests-Final report. www.illegal-logging.info/item_single.php?it_id=38\&it=document [Accessed 14 January 2015].

Greenpeace (2014). Weaker certification schemes. Other forest industry driven certification schemes fail to meet basic performance indicators. Available at: http://www.greenpeace.org/international/en/campaigns/forests/solutions/alternatives-toforest-destruc/Weaker-Certification-Schemes/ [Accessed 14 December 2014]. 
Kemitraan (2014). Terobosan baru dalam SVLK: conformity declaration untuk hutan rakyat dan industri kecil menengah. Available at: http://www.kemitraan.or.id/sites/default/files/ Press\%20Release\%20Self\%20Declare\%20SVLK\%20Kemitraan-160514final.pdf [Accessed 14 March 2015].

Kompas(2014). Ini aturan baru legalitas kayu. Available at: http://bisniskeuangan.

kompas.com/read/2014/12/30/090900326/Ini.Aturan.Baru.Legalitas.Kayu [Accessed 14 January 2015].

LEI (Lembaga Ekolabel Indonesia) (2013). FMU and Manufacture LEI Certified. Updated: July 2013. Available at: http://www.lei.or.id/files/FMU\%20\&\%20Manufacture\%20certified\%20LEI July\%202013.pdf [Accessed 14 November 2014].

LEI (Lembaga Ekolabel Indonesia) (2014). Laporan Kegiatan Lembaga Ekolabel Indonesia 20092014. LEI.

MFP (Multistakeholder Forestry Programme). (2014). SVLK: Meningkatkan perdagangan produk kayu legal dari Indonesia. Infobrief, December 2014. Available at: http://www.mfp.or.id/ attachments/article/89/SVLK\%20in\%20brief_IND_FA.pdf [Accessed 14 January 2015].

MoEF (Ministry of Environmental and Forestry) (2014a). Ministry Regulation No P. 95/MenhutII/2014 on Ministry Regulation No P. 43/Menhut-II/2014 on performance appraisal of sustainable production forest management and timber legality verification.

MoEF (Ministry of Environmental and Forestry) (2014b). Circular letter from Director General of Forest Enterprises No: SE.14/VI-BPPHH/2014 on concerning obligations fulfillment related to timber legality verification system (SVLK).

MoF (Ministry of Forestry) (2009). Ministry Regulation No P. 38/Menhut-II/2009 on Performance appraisal standard and guidelines of sustainable production forest management and timber legality verification.

MoF (Ministry of Forestry) (2011). Ministry Regulation No P. 68/Menhut-II/2011 on First amendment of Ministry Regulation No P. 38/Menhut-II/2009 on performance appraisal standard and guidelines of sustainable production forest management and timber legality verification.

MoF (Ministry of Forestry) (2012). Ministry Regulation No P. 45/Menhut-II/2012 on Second amendment of Ministry Regulation No P. 38/Menhut-II/2009 on performance appraisal standard and guidelines of sustainable production forest management and timber legality verification.

MoF (Ministry of Forestry) (2013). Ministry Regulation No P. 42/Menhut-II/2013 on Third amendment of Ministry Regulation No P. 38/Menhut-II/2009 on performance appraisal standard and guidelines of sustainable production forest management and timber legality verification.

MoF (Ministry of Forestry) (2014a). Ministry Regulation No P. 43/Menhut-II/2014 on performance appraisal of sustainable production forest management and timber legality verification.

MoF (Ministry of Forestry) (2014b). Circular letter from Director General of Forest Enterprises No: SE.8/VI-BPPHH/2014 on concerning obligations fulfillment related to timber legality verification system (SVLK).

MoF (Ministry of Forestry) (2014c). SVLK development, Commitment to sustainable forests for sustainable trade.

MoF (Ministry of Forestry) (2013b). Keunggulan SVLK sebagai penguat produk nasional. Seminar Kehutanan Indonesia, Jakarta 16 Desember 2013. p.42. (presentation file).

MoF (Ministry of Forestry) (2014). Data PHPL. Available at: http://www.dephut.go.id/ index.php/common/phpl [Accessed 14 March 2015].

MoT (Ministry of Trade) (2012). Ministry Regulation No. 64/M-DAG/PER/10/2012 on Export provision on forest industrial products. 
MoT (Ministry of Trade) (2013a). Ministry Regulation No. 81/M-DAG/PER/12/2013 on Amendment on Ministry Regulation No. 64/M-DAG/PER/10/2012 on export provision on forest industrial products.

MoT (Ministry of Trade) (2014). Diplomasi perdagangan Wamendag di London: SVLK berdampak positif bagi ekspor kayu Indonesia. Available at: http://www.kemendag.go.id/id/news/ 2014/06/04/diplomasi-perdagangan-wamendag-di-london-svlk-berdampak-positif-bagiekspor-kayu-indonesia [Accessed 14 December 2014].

Neraca (2014). Usaha kecil akan dibantu sertifikasi legalitas kayu. Available at: http://www.neraca.co.id/industri/43685/Usaha-Kecil-Akan-Dibantu-Sertifikasi-Legalitas-Kayu [Accessed 14 January 2015].

The Jakarta Post. (2014a). Indonesia aims long-term timber export growth in EU. Available at: http://www.thejakartapost.com/news/2014/03/01/indonesia-aims-long-term-timberexport-growth-eu.html [Accessed 1 January 2015].

The Jakarta Post. (2014b). APKI wants more access to local market. Available at: http://m.thejakartapost.com/news/2014/07/19/apki-wants-more-access-local-market.html [Accessed 14 January 2015]. 